\title{
Strategy of Enhancing Corporate Competitiveness through Operational Digitalization: Case of Axa France
}

\author{
Thierry Fleury Medard Denamguere, Xiangfeng Wu, Sokai Wiltord, Padou Maxime \\ Faculty of Management and Engineering, Department of Science Economics and Management, Chongqing University of Posts \\ and Telecommunications, Chongqing, China \\ Email: fdenamguere@yahoo.fr, wuxf@cqupt.edu.cn
}

How to cite this paper: Denamguere, T.F.M., Wu, X.F., Wiltord, S. and Maxime, P. (2018) Strategy of Enhancing Corporate Competitiveness through Operational Digitalization: Case of Axa France. American Journal of Industrial and Business Management, $\mathbf{8}$, 1460-1468.

https://doi.org/10.4236/ajibm.2018.86098

Received: May 5, 2018

Accepted: June 9, 2018

Published: June 12, 2018

Copyright $\odot 2018$ by authors and Scientific Research Publishing Inc. This work is licensed under the Creative Commons Attribution International License (CC BY 4.0).

http://creativecommons.org/licenses/by/4.0/

\begin{abstract}
It has been several years since trade was born between companies and different nations, or the World Trade Organization (1994) completed the idea in the context of carrying out their commercial activity without having many barriers. The evolution of the new technology has allowed a new economic boom, in order to reinforce and reinvigorate the capacity of human resources, making a state of place on the digitalization requiring a strategy of the company in the digitization and the practices to the method, going through a feasibility study that the group Axa had looked into, in order to be able to engage in competitiveness. This study has allowed us, therefore, to give concrete proposals related to the situation in which the group is complementing the work that has already been done by our predecessors, to be able to possess economic, political and cultural reforms.
\end{abstract}

\section{Keywords}

Corporate strategy, Competitiveness, Digitalization

\section{Introduction}

Nowadays, we are all witnessing the change in business activities among firms through the phenomenon of new technology, some approaching each other in several ways to acquire goods and services (Markusen and Brainard, 1997). Companies are looking for each other to maximize profit, facing multiple forms of competitiveness (Alfred Sloan, 48-49, 1990 edition, [1]). So competitiveness can be defined in general terms as the ability of a country or a company to maintain or increase its market share compared to its competitors (N. Venkaty- 
raman 1995, [2]). In the following, the quality of competitiveness is one of the priorities in determining the economic policy of each country. Digitalisation has just completed the way of working, by revitalizing and reorganizing the management system and the reinforcement of human resources capacity. Quality theories emerged with the industrial revolution and the establishment of a Taylorist or Fordist organization (Pascallon et al. 1984, [3]). The close link of competitiveness to quality first requires a better consideration of the service that accompanies the product. As a result, the quality through its approaches supposes to better valorize the different forms of creativity and innovation in all the sectors (design, marketing, new economic models, innovations of use etc.).

Indeed, historically speaking, the strategy comes from the Greek words: "stratos" which means army and "argos" which means I drive (Gervais, 1989, [4]). Etymologically, the strategy is the conduct of armies; this idea appears in the world of business, that is to say, prevented from progressing competitors. It is no longer the physical force that functions but the intelligence, the gray matter that can react in complete peace of domination over the other competitors. According to Porter, the Company's strategy is the art of building sustainable competitive advantages (1982). So, for competitiveness to be effective and the digitalization of marketing that is effective in the goods and services market, it will take the business strategy to analyze first before acting out. It is the reason why this article wants to describe the analysis of e-commerce factor influencing the competitiveness via the channel of the digitalization and in the end to give a general point of view.

\section{Corporate Strategy in the Digitalization}

The reorganization of the study plan and the business plan while more or less modifying or supplementing the initial investments (Goos et al. 2009, [5]).

Further consolidation of the company's internal activities and will play a role particularly in the field of marketing, can help influence some customers expectations through information disseminated to them, SALGUES (Floriane, 2015, p. 7072, [6]). Taking an example of shopping trends in particular Brazil, more than $80 \%$ of purchases being made are as a result of prior online research; another example from the United Kingdom has its banking sector exceeding 30\% and grocery stores stands at more than $10 \%$. As a result figures in excess of $75.6 \%$ of companies in the world are planning and or prepared to invest heavily in digitization, Greiner (Christine, 2015, pp. 118-123, [7]), evoking the analysis and reflection on the importance of the role to be played by the leader in the digitization strategy. In this light we retain two types of practices from this article was named below:

\subsection{The Practices of the Digitalization Strategy}

Practices are largely in the technical and organizational service of the company.

1) There is the so-called platform clustering of a digital platform economy, 
Laugier (Edouard, 2016, pp. 2-3, [8]).

2) Information Technology (IT) tools such as: laptops, tablets, fixed phones, cellular phones (M-commerce).

3) Access to the internet ultimately reduces the distance between the producer and the consumer to make their transactions go through without any obstacles or barriers (TCHENG (Henri) HUET (Jean-Michel) CHEVALLIER (Sylvain), 2016, pp. 96-100, [9]). The internet will be able to contribute very significantly to one or more dimensions of the company in favor of its business model, (Trehorel (Laurel), December 2015-January 2016, pp. 19-23, [10]).

Therefore, for a company in the digital transformation phase of these activities, we will have to focus on the keys to success, that is to say the keys to successful digital transformation, which are as follows:

a) Define a vision and share it;

b) Develop the skills of employees;

c) To evolve together all services;

d) Define a method of implementation;

e) Define governance;

f) Grant the business and IT departments.

These digital strategy practices, aimed at maximizing commercial benefits in the goods and services market. These digital strategy practices improving human performance, because this performance is the essence of the strategy of a digital practice and creates a certain type of value that will lead to the income of each employee and as a result will bring about gains in well-being and an increase in jobs (Mokyr et al. 2015, [11]). Then, these practices of the digital strategy make that increase the number of jobs but will not disappear those which are already before (Autor and Handel, 2013, [12]).

\subsection{The Practices Method}

The practices method is done through computer tools (computers, telephones, internet etc.) will now allow to partially erase routine work (Autor and Dorn 2013, [13]). Computers replace these routine jobs most likely to the advantage of digital within the company (Marcolin et al. 2016, [14]).

The practices method is done through IT tools (computers, telephones, internet etc.) will now allow companies to substitute in digital operations in place of traditional systems. Computers replace these routine jobs which are advantageous to the company and also add to the advancement of digital technology in the company.

1) This method may provide a good platform for education and it may be said that some workers with low education level might be disadvantaged at the start]. To cater for the above anomaly a reorientation can be done in the normal sense of focusing on the reform of the staff that is in the exercise of their function, to reinvigorate or strengthen the capacity of materials to adapt to this new change to achieve the satisfaction for all. The practice method constitutes a device of at- 
tractiveness of the customers, through the system of digital marketing, because ecommerce comes as the most convenient method in information dissemination.

2) E-commerce as a method has become commonly used, and its popularity is increasing rapidly through the world market. Through e-commerce a normal transaction can be done between the producer and the customer that some countries feel satisfied such-is the case of Brazil, according to a survey made in $2001,85.6 \%$ of customers in were satisfied with the services offered by the country's traders (IDG computer world do Brazil, 2003), (PARISOT (Thierry), 2015, p. 24., [15]). As a result, this method of practice is also considered necessary to support small and medium-sized enterprises in their growth. In recent years there have been efforts including a workshop organized by the World Trade Organization on 8 and 9 April 2013 with the aim of highlighting the link between trade and development. This was aimed at examining how small and medium sized businesses can use e-commerce for the promotion, marketing, maintenance and sell of their products both domestically and abroad, (Delapierre, C. Milelli, 1993, [16]).

3) The company maximizes digital opportunities through an Omni centric consumer-centric strategy by connecting its customers to its internal operations and finally to its supply chain.

Thus, we now know that the Internet has become a common way for businesses to carry out business activities in several ways (computers, cell phones, tablets, etc.). The practice of using the internet has allowed rapid development of e-commerce. Figure 1 goes to show us the number of Internet users per capita in 2011.

Then e-commerce has become indisputable and has grown rapidly for the benefit of web-users in search of products and services, the magazine of the consumer, September 17 2015, pp. 40-42, 44-50, 52-54, 56-58, 60-61, [17] and make their decision to buy what they want (FENOLL (Marie-Amélie), Procurement Decision, February-March 2016, p. 12, 14, [18]).

\section{Review Organization}

The organization of an examination in relation to all these practices used,

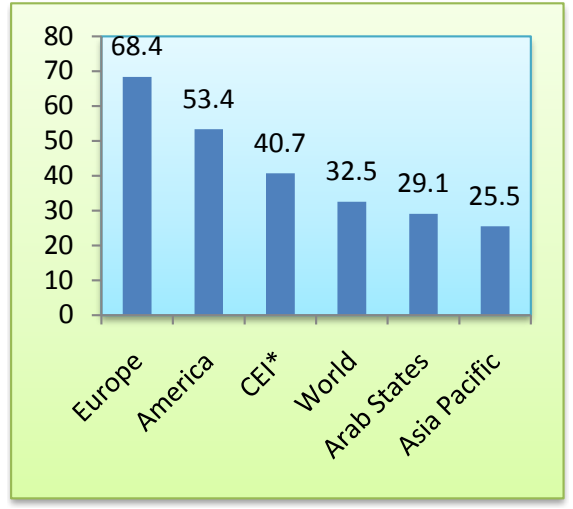

Figure 1. The number of internet users per 100 inhabitants, 2011. 
requires an analysis that can be done, to be able to know more the importance or the utility of a digitization application that can also increase the growth of a company and the creation of new jobs, (Frey \& Osborne, 2016). The result for a company by using digitalization is to have access to several markets so that it can increase its market share. On the occasion of the Digital in store and e-commerce exhibitions organized at Paris Expo, September 2015, saying that the human resource still has its place playing the role of providing added value in the interaction with customers (Batteux (Catherine) March 7-April 3, 2016, pp. 40-41, [19]).

His result by using digitalization, is of course, related to the insurance company Axa Group which saw its turnover up 2\% to 90.1 billion Euros and the creation of new businesses such as direct sales, an activity that was profitable in 2012. This result of this group is always changing it is simply the contribution of digitalization in its activities to achieve the desired result. Witnessed by the graph attached below, we can easily see the trend of this evolution through its employees since 1980 up to 2002, 130,000 employees (employees and exclusive distributors) work for the AXA group. In 20 years, the group's workforce has been multiplied by more than 75 .

(http://www.institut-entreprise.fr/sites/default/files/publication/.../AXA.pdf)

This being a significant increase, this group is still hoping to thrive further around the world. This is to say that the number of its employees continues to grow more until now. The observation will be made by Figure 2 .

So Axa's competitiveness, estimates a 200 million euro realization of additional savings compared to the target of 1.5 billion set in 2015, but at first it was a small insurance company French created in 1817, and its turnover nowadays will be represented by Figure 3 as follows.

Another result by using digitalization is that the conquest of the Asian market has raised the group, to consolidate its internationalization and accelerate its development in Asia, the group is betting on innovation. "Asia is at the forefront of digital," says Jean-Louis Laurent Josi, director of Asian activities of Axa citing

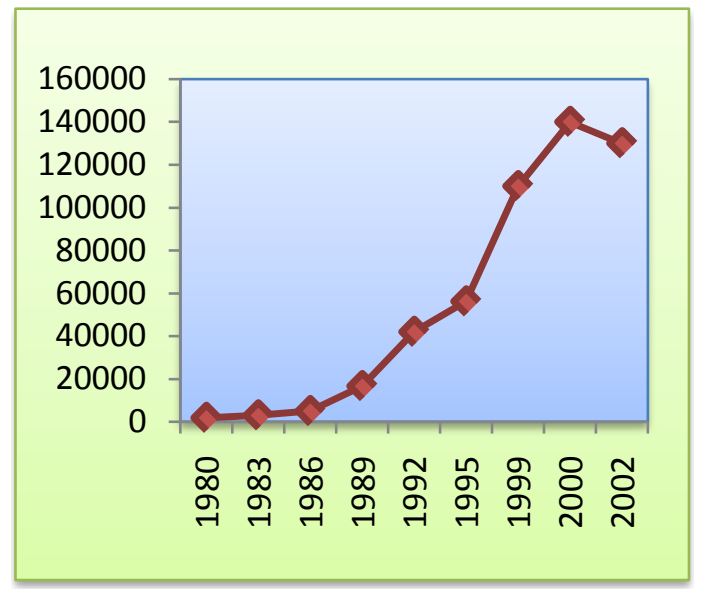

Figure 2. The evolution of Axa group employees from 1980 to 2002. 


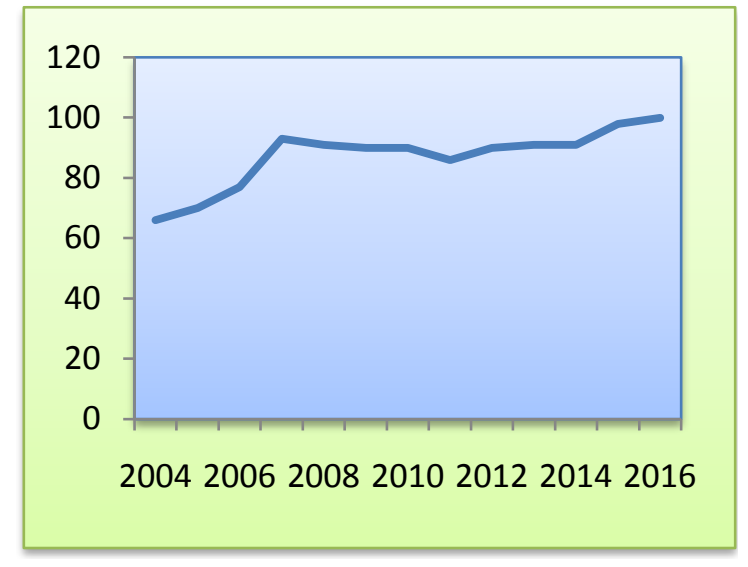

Figure 3. Financial data in millions for Axa group 2004 to 2016.

the weight of e-commerce ( $\$ 450$ billion in China), the number of mobile users in Asia (3.3 billion), access rates to the Internet from a Smartphone (90\%) or the craze for social networks ( 1.8 billion users). The Axa group recorded a net profit up 7\% to 6.2 billion Euros and also it's net profit up 6\% (+8\% at constant exchange rates) to 6.457 billion and also records $6 \%$ up its operating result 2017 . The analysis focuses on facts that many companies feel interested in practices. The strategy that they can put in place, goes in the direction of the financing of the training put at the disposal of the human resource in order to obtain a satisfactory result, (MORIN (Cédric), 15-29 February 2016, pp. 30-31, [20]). This analysis will focus on the AHP model, developed by Saaty (1970) in the context of making a decision, so we will focus on, to be able to see the influence of e-commerce on competitiveness, the model is thus (Table 1):

$$
\mathrm{CI}=\frac{\lambda M a x-n}{n-1}=\frac{5.54-5}{5-1}=\frac{0.54}{4}=0.135,
$$

CI: consistency indices

$$
\mathrm{CR}=\frac{\mathrm{CI}}{\mathrm{RI}}=\frac{0.135}{1.12}=0.1 \sim 10 \%,
$$

CR: consistency rate.

These data were collected from the specialists randomly, that is to say we made the questionnaire submit to them. Starting from there, we have possessed in this calculation, after having finished, we then check being able to note the reality of the influence of e-commerce on the competitiveness. Figure 4 below will fit us the model application.

These indicators and sub-indicators are built according to the title of the article, and the design of the model followed is from Saaty (AHP) (1987). Analysis hierarchy process is used to make a decision while analyzing at the same time the issue of the decision that will be taken; this is the case of the Axa group.

1) Indicators:

Market: 0.396; Finance: 0.218; Human resource: 0.188; Innovation; 0.138; Industry risk: 0.028 
This initial figure will allow us to make a verification calculation that is to say, to find out what e-commerce has an influence on competitiveness. Then our objective is to reach a result one (1) so that we can later confirm this influence. Therefore, by possessing this calculation, it will lead us to develop another figure in order to evaluate a reciprocal reality in accordance with the functioning of the market and the distribution channels of goods and services, by Figure 5 .

2) The Sub Criteria:

Market share: 0.5766; Marketing: 0.1033; Increase the ratio: 0.3066; Total assets: 0.31; Assets liability ratio: 0.19; Net profit ratio: 0.6933; Employee productivity: 0.5066; Employee satisfaction: 0.3266; Educational degree: 0.46; Research and development for the company: 0.75; Rate of the new product: 0.25 .

3) Either the Verification:

$\mathrm{A} 1=\mathrm{A}^{\star} \mathrm{a} ; \mathrm{A} 2=\mathrm{A}^{\star} \mathrm{b} ; \mathrm{A} 3=\mathrm{A}^{\star} \mathrm{c} ; \mathrm{B} 1=\mathrm{B}^{\star} \mathrm{d} ; \mathrm{B} 2=\mathrm{B}^{\star} \mathrm{e} ; \mathrm{B} 3=\mathrm{B}^{\star} \mathrm{f} ; \mathrm{C} 1=\mathrm{C}^{\star} \mathrm{h} ; \mathrm{C} 2=$ $\mathrm{C}^{\star} \mathrm{i} ; \mathrm{C} 3=\mathrm{C}^{\star} \mathrm{j}$

$0.2155+0.0386+0.1146+0.0638+0.0391+0.1426+0.0899+0.0816+$ $0.0579+0.0977+0.0326+0.0063+0.0164+0.0035=1$

This is what has been done; we have reached the result of verification which is 1. So it is justifiable, the value 1 proving that e-commerce has an influence on the competitiveness of the group Axa.

Table 1. Pairwise comparison for competitiveness (Initial group).

\begin{tabular}{cccccc}
\hline & Market & Finance & Human Resource & Innovation & Industry Risk \\
\hline Market & 1 & 3 & 4 & 2 & 7 \\
Finance & $1 / 3$ & 1 & 3 & 2 & 5 \\
Human Resource & $1 / 4$ & $1 / 3$ & 1 & 4 & 6 \\
Innovation & $1 / 2$ & $1 / 2$ & $1 / 4$ & 1 & 7 \\
Industry Risk & $1 / 7$ & $1 / 5$ & $1 / 6$ & $1 / 7$ & 1 \\
Total (Sum) & 2.22 & 5.03 & 8.41 & 9.14 & 26 \\
\hline
\end{tabular}

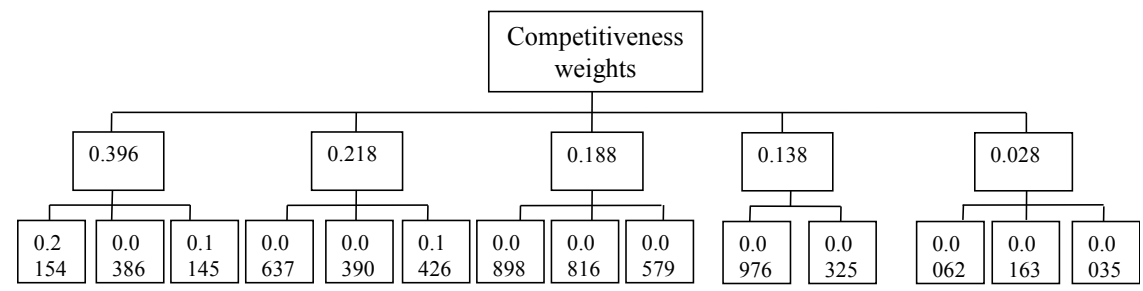

Figure 4. Application of the model.

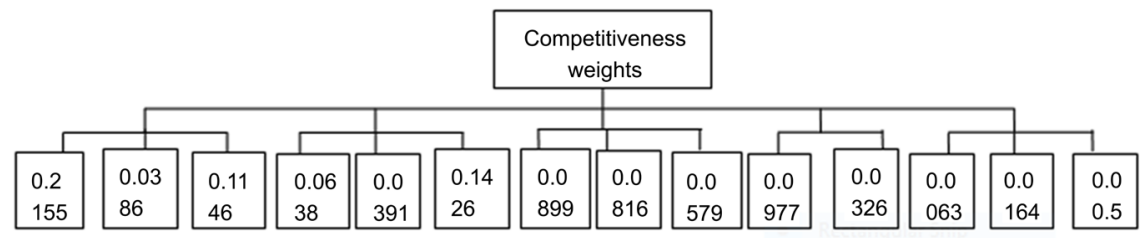

Figure 5. The model reaches of competitiveness weights. 


\section{Summary \& Conclusion}

\subsection{Summary}

We are supposed to know all the parts that seem necessary to the operation of a strategy of digitization of the company, because there are the practices, the method and the revision of the organization which should be done in a general way in the stakeholder contest without so much deterioration of the old systems, and there is obviously a change in the expectation of consumers. All these methods and practices have a cost to support the company, and afterwards to release a result, and this result is the essence of the motivation of the company to invest more in a well defined context that is to draw its growth upwards.

\subsection{Conclusion}

In this article, methods and practices determine the ability of a company to access a foreign market; the advantage is that digitalization is a strong point in controlling the necessary activities and waiting for consumers. Then the usefulness of the digital tools allows the company to reinforce the efficiency of its tasks and daily process vis-a-vis its competitors. The search for a qualified workforce and the competence of human resources fall within the framework of asserting the potentiality to innovate materials and the reorganization of internal activities that can be done. So it will take the search for capacity building of its management and the information collected online to develop and personalize its services and products, and allow making profit. Therefore, to strengthen its ability not only in human resource but also to revitalize its materials to keep its performance in competitiveness, influenced by e-commerce, the expectations of consumers have already changed. Indeed, the Axa group will be able to focus on its different methods and practices to remain competitive while knowing that the influence of electronic commerce can bring more value, more growth, both for the benefit of consumers and research of development. Recalling that the group had a good performance in 2016 , its turnover increased by $2 \%$ to 100,193 million Euros on a comparable basis, exceeding the 100 billion mark for the first time in history of the Group http:www.axa.com/fr/a-propos-d-axa/chiffres-cles. This is the useful result of the digitization strategy for greater competitiveness and the satisfaction of all, because a long-term work has already been done by our predecessors, and this has just completed in the program of all companies that want to embark on this adventure.

\section{References}

[1] Fenoll, M.-A. (2016) Purchasing Decision, p. 12, 14.

[2] Batteux, C. (2016) Digital. Anticipating the Trades of the Future, Retail Outlets, No. 1190, 40-41.

[3] Parisot, T. (2015) IDG Computer World Do Brazil. p. 24.

[4] Sloan, A. (1990) The Generality of Competitiveness. 48-49.

[5] (2015) The Magazine of the Big Consumer. September 17, 40-42, 44-50, 52-54, 
56-58, 60-61.

[6] Laugier, E. (2016) The New Economist. April 15, No. 1812, 2-3.

[7] Salgues, F. (2015) Business Marketing. 70-72.

[8] Tourneur, J.-C. (2015) Digital Transformation Strengthens Quality Assurance Testing. 20-21.

[9] (2015) The Argus of Insurance. Social Networks-Digital Transformation. Decluttering to Better Communicate and Innovate, March 20, No. 7401, p. 1417.

[10] Triquet-Guillaume, M. (2015) Human Resources: Getting Organized for Digital Transformation. IT for Business, No. 2200, p. 6778.

[11] Tcheng, H., Huet, J.-M. and Chevallier, S. (2016) Expansion. No. 812, 96-100.

[12] Del Pozo, A. (2015) Transformation digitale des entreprises. December, 6-10, 1226.

[13] Gröne, F., Lefort, T. and Kropiunigg, L. (2015) The Impact of Digitization and the Internet on the Creative Industries in Europe Olaf Acker.

[14] Markusen, J.R. (1997) Multinational Firms and the New Trade Theory. August 18, 183-203.

[15] Mokyr, J., et al. (2015) The History of Technological Anxiety and the Future of Economic Growth: Is This Time Different? Vol. 29, No. 3, 31-50.

[16] Michel, D. and Christian, M. (1995) Multinational Firms. Companies at the Heart of Globalized Industries.

[17] Venkatraman, N.V. (1995) Measurement of Business Performance in Strategy Research: A Comparison of Approaches. 801-814.

[18] Tanriverdi, H. and Venkatraman, V. (2005) Knowledge Relatedness and the Performance of Multibusiness Firms. 97-119.

[19] Autor and Dorn (2013) The Growth of Low-Skill Service Jobs and the Polarization of the US Labor Market. Vol. 103, No. 5, 1533-1597.

[20] Pascallon (1984) Introduction to Social Systems Engineering. eBook, 23-24, 52. 